\title{
Stakeholders Identification Affecting the Scope and the Changes in the Health Care System
}

\author{
Joanna Jasińska ${ }^{1 *}$ and $\mathrm{Hab}^{2}$ \\ ${ }^{1}$ Faculty of Medical Sciences, Masovian Medical School, Vice-Rector for Education and Development, Poland \\ ${ }^{2}$ University of Social Sciences Computer Science and Medicine, Vice-Rector for Education and Development, Poland \\ *Corresponding author: Joanna Jasińska, University of Social, Computer \& Medicine Science, Warsaw, Poland
}

\begin{tabular}{|c|c|}
\hline ARTICLE INFO & ABSTRACT \\
\hline Received: April 29, 2020 & \multirow{3}{*}{$\begin{array}{l}\text { Changes taking place in healthcare require the involvement of everyone entities } \\
\text { operating in the system. However, not all stakeholders have the same options for } \\
\text { influencing system reform. It depends on many factors, such as ownership power, } \\
\text { knowledge or the right tools. The most interested changes the group is patients, but their } \\
\text { strength is relatively small. Quite differently the situation is, if we look at pharmaceutical } \\
\text { concerns: definitely less interesting their changes and their potential for impact are } \\
\text { much greater. The article presents what entities participate in introducing changes in } \\
\text { health care and what are their real ones the possibilities of influencing the system and } \\
\text { why these possibilities (or lack thereof) result. }\end{array}$} \\
\hline Published: 恶 May 07, 2020 & \\
\hline $\begin{array}{l}\text { itation: Joanna Jasińska, Hab. Stakehold- } \\
\text { s Identification Affecting the Scope and } \\
\text { e Changes in the Health Care System. Bi- } \\
\text { med J Sci \& Tech Res 27(3)-2020. BJSTR. } \\
\text { S.ID.004512. }\end{array}$ & \\
\hline
\end{tabular}

Keywords: Stakeholders; Change; Health Care; Health Care System

\section{Introduction}

The necessity to introduce changes in health care, especially in the recent period, is not in doubt. However, this is not an easy or cheap task. For state and patient finances, for the health security of society, the situation of making changes requires constructive planning of the effects of change. Experts for several years show what changes would be beneficial, in which direction health care should be reformed, what solutions would bring the greatest benefits to all participants in the system. Observing changes in health care, it can be concluded that among many stakeholders operating in the system only some have a real impact on their introduction, type and course. The imbalance results from many factors related to the specificity of the system and its participants, the nature of changes and the political situation. The purpose of the work is to identify stakeholders who potentially have the greatest potential to influence the scope and course of changes in the healthcare system, and the sources of these possibilities.

\section{Stakeholders}

One of the difficulties of reforming the health sector is the large number of entities that operate under the health care system. We can call them health care stakeholders. Stakeholder theory was initiated by the Stanford Research Institute in 1963, it concerned organizations and proclaimed that stakeholders were groups without whose support the organization could not function. Now in 1984, Freeman decided that stakeholders were all individuals and groups in and around the organization that have an impact on the organization's goals or on which the organization could influence achieving its goals [1]. Therefore, it should be recognized that stakeholders will not be those units or groups that cannot influence the organization. Stakeholders can also be divided into internal and external. Internal is usually employees, management, shareholders and the supervisory board. Customers are external, competitors, suppliers, trade unions and state authorities [2].

It is believed [3] that the stakeholder theory can be applied to public organizations. The main difference is that public organizations operate in a highly politicized environment and the choice of specific strategic reasons is dictated not by their actual assessment, but by the bargaining power of the most influential stakeholders. If we consider the fact that stakeholders in public organizations have very unequal access to power, it may turn out that selected groups not only influence the achievement of the organization's goals, but above all pursue their own goals. 
The introduction of fundamental changes in healthcare requires identifying one of the leading stakeholders and thinking about how they affect the introduction and course of changes in the system.

Stakeholders who may have an impact on health care include, among others:

1. Politicians (minister of health, health committees, parliament),

2. The payer (in Poland is the National Health Fund),

3. State healthcare institutions,

4. The management of health care institutions,

5. Private healthcare facilities,

6. Mid-level medical staff managed and

7. Patients

These are not all entities, as there are many more in the health care system and in its environment (e.g. insurers, pharmaceutical companies, trade union and religious organizations, suppliers, associations), however the authors mentioned can be considered the most significant.

\section{Changes in the Health Care System}

In modern healthcare organizations, the changes have acquired a completely new character, ceased to be a specific event at a specific time, and have become a permanent process. The same situation occurs in Polish healthcare. For some time, all participants have been constantly experiencing new changes that involve very different aspects of the system's functioning. This is not one big change in the whole system, but a string of introducing new solutions and innovations. This is not an easy situation for all interested parties. When making changes, the most important thing is to know what you want to change, plan the change, prepare people, make the change, and then control the adaptation. In practice, this is a very complicated process with many problems. Firstly, as a rule, there is no single idea for change, several variants of change methods are possible, and sometimes implementation in practice does not bring the planned effects. Secondly, changes always affect people, and this is the most unpredictable factor in the whole process. Changes disturb the existing order, raise fear of the unknown, threaten the economic situation and sense of security, and thus cause resistance from people to accept such solutions [4].

Most often the initiators of changes are individuals and small groups, and they concern large communities, sometimes entire societies. Health is the supreme value and is of great importance to people. The functioning of the system in which the state provides all health needs, because it has such an obligation, confirms the belief that health care is free, widely available. This results in such a high resistance of patients from introducing new solutions. They see any change as an attack on their rights to comprehensive, "free" health services. However, it is difficult to expect a different perception of health protection in the event of an epidemic threat to the whole society. The changes also raise the concerns of medical and administrative staff, especially since unprotected solutions are replaced in a short time by other, quite different, which have to be learned during work, i.e. by experimenting on patients. Often, these are also changes that are subject to financial risk incurred by a doctor or pharmacist, and in this situation this burden is shifted to the patient who, in fact, has no choice. Certainly, participants' resistance could be reduced by improving communication between decision-makers and those affected by this change, which is currently difficult.

S. Golinowska believes that the barriers that stand in the way of changes in health care are conscious and factual - real. In the sphere of consciousness there is:

1. Lack of comprehensive approach to the healthcare system.

2. Simplified diagnosis and numerous gaps in knowledge about the state of resources in the health care system and the quality of its management.

3. Selective knowledge about the processes of changing the healthcare system in other countries, leading to unreliable use of international comparisons.

4. Shaping the picture of the situation in health care mainly by the media, which uses selective information, with the dominance of sensational reports, often unreliable and often shaped by large interest groups.

5. Phenomena in the sphere of consciousness affect the formation of real processes and, therefore, lead to a deepening crisis in the system, which manifests itself:

6. Financial imbalance between funds flowing into the healthcare system and the costs of its functioning, leading to systematic indebtedness of health facilities.

7. Imbalance of development between the basic parts of the health care system: public health, healthcare, rehabilitation and long-term care.

8. Neglect of basic technical infrastructure and decapitalization of medical equipment.

9. Wage inequalities, corruption phenomena and outflow of medical staff abroad.

10. Lack of medical staff: doctors, nurses, midwives, medical carers, diagnosticians and other medical staff

11. Lack of institutional capacity to make decisions beneficial from the perspective of the healthcare sector: creation of a national hospital network, computerization, rational drug policy, ordering the division of competences. At the same time, taking organizationally justified decisions as reform activities. These are, 
for example, actions involving the liquidation or merger of some institutions, and the creation of others, insufficiently justified and introduced in advance changes to the criteria for financing health services, and as a consequence - introducing chaos and anxiety among patients [5].

In difficult organizational situations, to implement changes in phenomena occurring in the health protection system it is necessary to introduce new solutions that have limited the deepening crisis. The literature on the subject most often draws attention to the need for changes in the financing of healthcare, improvement of change management and implementation of effective organizational and competence solutions. In the sphere of management and organizational-competence solutions, the following are important:

1. Introduction of modern personnel management, appropriate quantitative and competence selection, staff training and development,

2. Creating the basis for analyzing the quality of medical services,

3. Creating information security about resources, services, patients,

4. Introduction of principles of rational distribution of facilities and standards of their equipment [6].

When it comes to the financial sphere, the first and essential step to the desired changes is to create an interdisciplinary basket of guaranteed services. Creating such a basket may cause some difficulties (especially in the event of an epidemic crisis). The problem may result from the selection of appropriate criteria for health services. Such benefits should be interdisciplinary: medical, economic and social. In addition, the implementation of these criteria requires numerous and ongoing analyzes of medical effectiveness and cost effectiveness. From the patient's point of view, the creation of such a basket is associated with the necessity of various payments when using the "non-basket" procedures. In situations where effective treatment is conditioned by the use of above-standard treatment, not covered by basic health insurance, it may turn out that such costs exceed the individual financial capabilities of the patient. To avoid such situations, in many countries the health care system is additionally supported by organizing the entire system of subsidies (co-payment).

The co-payment system takes various forms - small fees that are charged when using benefits, indirect fees, i.e. subsidies for tobacco products or alcohol, up to an increase in the premium for some compulsory insurance, e.g. civil liability of vehicle users. However, the main core are additional health insurance. According to the author, there is also no need to change solutions that work and work well, such as organizational changes in a medical emergency. However, there are also areas that require decisive changes, such as the functioning of hospitals (in the event of an epidemic), the valuation of services, management of health care facilities, computerization (knowledge of resources), quality and availability of health services.

\section{Impact of Individual Stakeholders on the Introduc- tion and Course of Changes in Health Care}

All necessary changes in health care should have one main goal: improving the functioning of the system while not compromising its functioning, which will allow to meet the health needs of society. Stakeholders play a leading role in this process, as the type, direction and success of the changes depend on them.

\section{Minister of Health, Health Committee, Parliament}

Politicians are the stakeholder group that has the greatest impact on initiating changes in health care, their type and course. The health care system belongs to the public sphere, for which parliament and government are responsible, elected in democratic elections as representatives of society. The system is based on laws, ordinances and other documents adopted by the parliamentary majority. New solutions are most often proposed by the government, MPs or senators, less often by the citizens themselves. Which solutions will be adopted often has no relation to type or quality. The strength of parliament is enormous, because it establishes the law, which is then implemented at all levels in the system. Unfortunately, it happens that the idea for change is unsuccessful, hinders functioning and creates the need for another change. Key decisions are made in parliament that are relevant to all health care stakeholders because they relate to the shape and functioning of the entire system.

\section{The Payer (in Poland is the National Health Fund)}

The payer receives money from health insurance premiums paid by patients. It concludes contracts for the provision of health services with entities providing such services and evaluates individual medical procedures. Due to the position of the financial monopolist, he gains great opportunities to influence the functioning of the health care system. Entities providing medical services have little influence on the amount of concluded services or their price. This situation raises many dangerous phenomena, e.g. a hospital pays to treat a patient who is in the ward for more than a certain number of days, or patients with specific diseases whose treatment is highly priced are admitted. By its activities, the payer of medical services does not promote well-managed hospitals, with rational resource management, and high quality of services rendered, which means that weak units sometimes have the same contracts as modern, specialized centers. The payer of medical services, as a central entity under the authority of the state, cannot function independently. This dependence on the government, and at the same time the role it plays, means that it can be included in the bodies with a high potential to influence changes in the health care system. 


\section{State Healthcare Institutions}

In considering the impact of individual stakeholders on changes in health care, one very important thing should be taken into account, namely the form of ownership of health care providers. Owners, because they can very intensively change health care. In Poland, most hospitals are public facilities. The liquidation, transformation, sale or closure of the facility is the responsibility of the public owner (local governments or the Ministry of Health). Of course, public ownership bodies (appropriate depending on the entity's reference level) are required to meet the health needs of residents in the area. However, with ever decreasing budget revenues, less money is being allocated to health and the shortage of medical staff, public owners have problems, especially in the event of an epidemic emergency.

\section{The Management of Health Care Institutions}

Knowledge, cooperation skills, openness, loyalty to organizations and employees, creativity, dynamism and activity of activity, optimism and ability to manage change are the basic features of the image of a healthcare organization manager. The structure of these features, and others can be included in their collection, is not particularly specific if the essence of managerial work in healthcare is presented in a general way. As in other areas of managerial activity, there are also consequences for this staff that appeared along with the systemic change. Managerial work and management roles are also affected by changes observed from a global, macro and microeconomic perspective. Understanding and accepting their presence and taking into account their impact on management activities are undoubtedly new challenges for the management of healthcare organizations. Such a challenge, using M. Crozier's proposal, is to include in the content a managerial role, the role of a social innovator who is able to connect people and ideas and engage them in the processes of solving complex problems of the reality in which we live [5].

However, special changes in managerial work in healthcare organizations should be associated with social change. They broadened the scope of decision-making independence of the manager and outlined the area of responsibility, which until these changes was based on different principles and was shaped on a different basis.

The management of health care institutions plays a much greater role in implementing and monitoring the course of changes [E.C. Shapiro]. Managers responsible for implementing new solutions are required to prepare the ground for changes. This is primarily related to the preparation of employees: highlighting the need to introduce changes, presenting the benefits and threats, gaining acceptance for change. As already mentioned, this is a key moment for the successful introduction of innovation. Of course, in small units, the task of the manager is easier. Employees identify more with the workplace, relations with the manager are often direct, employees are involved in the decision-making process.

In large entities, especially where employee interests are defended by trade unions, managers have a difficult task. The differences also result from the ownership of individual entities. In public works, managers are subject to the public owner and act in accordance with the law on public organizations. In private factories, many changes do not result from the need to apply the law, but from the owners' ideas for modernizing the facility, introducing new services, increasing quality or applying new technologies. Managers must meet the expectations of owners and skillfully manage changes.

\section{Private Healthcare Facilities}

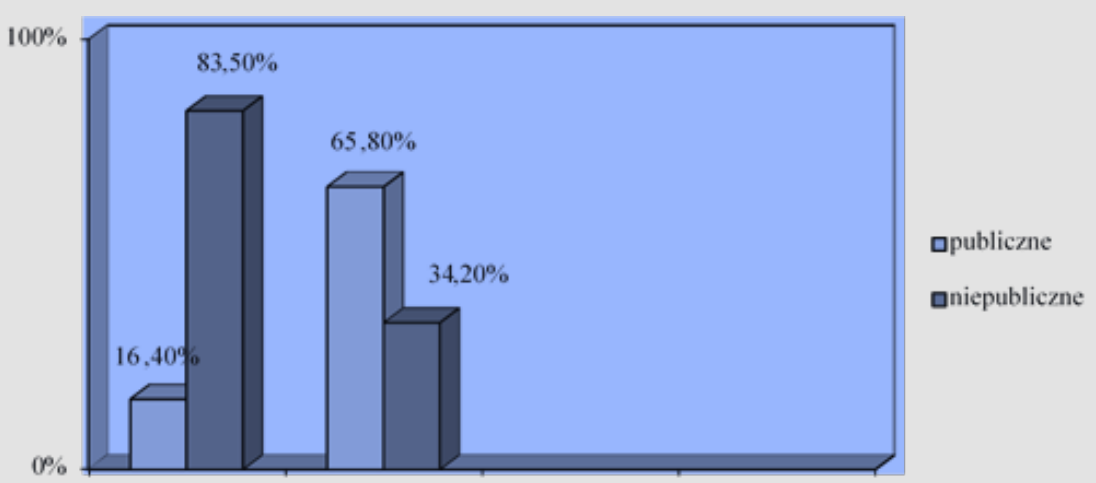

Source: own study based on: Health and health care in 2018 in Polen, Central Statistical Office, Warsaw 2019.

Figure 1: Percentage share of public and private entities on the market of health services broken down into hospitals and outpatient care.

Private healthcare facilities are competitors on the market of health services for public entities. These are plants that most often have private owners and private property, but work under a public contract. The growing share of this type of entities in the total number of all health care facilities (Figure 1) may indicate that most changes will be prepared for this type of facilities. New solutions will have to be adapted to the expectations and specifics of the operation of private healthcare facilities. In the event of 
introducing additional health insurance or separating the payer function, further increase in the number of private entities in other areas of the healthcare system can also be expected.

\section{Mid-Level Medical Staff Managed}

Middle management has a special role to play in the process of change. These personnel are most often described in the literature as the "executor" of top-level management instructions. R. Kanter defines the position of middle management in the organization as "... squeezed between the requirements of strategies beyond their control and the ambitions of independent thinking employees ...". Growing uncertainty means that there must be changes in the area of activity of employees of "contractors". It should be noted that modern organizational concepts limit their activities to key areas. This view may lead to the conclusion that middle management can be replaced by technology or computerization. Everything to "flatten" the organizational structure. This in turn may mean that the average level of management loses its function. The organizational structure is flattened, and control functions can be performed, e.g., by top management.

E.C. Shapiro believes that management theorists are constantly "coming up" with new organizational structures. All these proposals limit the importance of middle management. Are employees losing importance because the environment is complex? According to the authors, management theorists - probably yes, according to practitioners - no. The middle management position can be seen as a simple management process [7]. H. Willke notes that management concepts refer to planned changes and, as he writes, there is a "center" capable of observing the results of changes $[7,8]$. New strategic initiatives are emerging in planning changes, as W. Bonsiep and J. Klich notes, through interactive processes in the organization and up and down hierarchy levels. Therefore, the authors are in favor of including the average level in activities related to elections and reorganization activities [9]. They emphasize that the active inclusion of an average level of the organization in the change process contributes to:

1. Increasing motivation to change,

2. Obtaining and processing information necessary in the reorganization process,

3. Average staff is the "link" explaining possible information disruptions,

4. Enables effective management in large organizations.

The figure below shows the information processing cycle. It indicates that the amount of information processed at the top management level prevents the creation of detailed organizational change plans (Figure 2). This is due to the lack of chance to implement the given intention without consulting the middle management level.

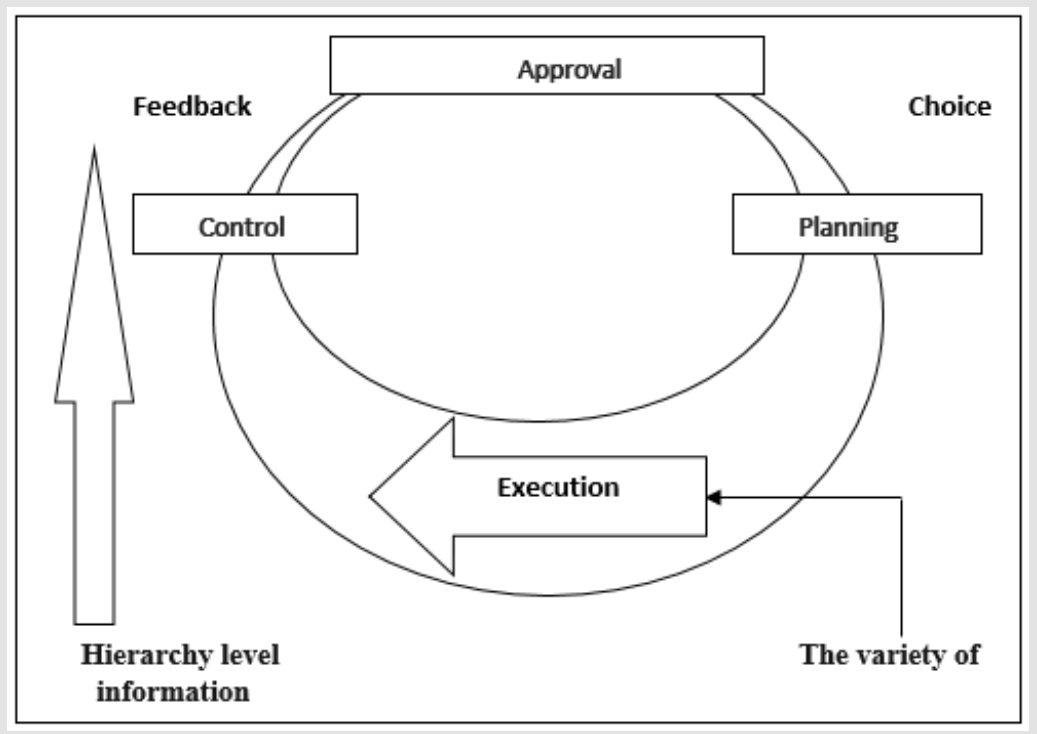

Source: W. Bonsiep, J. Klich, Mid-level managers - the barrier to change or a key factor of change, Przegląd Organizacji, No. 2, 2019, p. 20-21.

Figure 2: Hierarchically oriented information processing cycle.

There are other arguments in favor of recognizing the role of middle management as an important "actor" of the change process. Z. Mikołajczyk presents the opinion that there are known cases of unsuccessful attempts to implement changes without obtaining mid-level management support [10]. In the opinion of W.D.Guth and I.C.Macmillan, "... mid-level managers can take over the role of intermediaries between top-level management and regular employees [11].

Yet another importance of middle management in change management results from the participation of each member of the organization in the efficient and effective implementation of 
change. Middle management also participates in all phases of the management process. It should also be remembered that they are the basic source of innovation in the organization. Recognizing the significant role of middle management, it is important to include them in the reorganization process and, above all, provide them with information so that the planned change can be understood and accepted. Against this background, the question arises: how can they object to new solutions? There is no definite answer to this question. Perhaps it will be brought closer by a field of knowledge called partner management, whose guiding idea is that organizations be "closer" to the people who create them.

\section{Patients}

The change considered in the subjective area of the organization focuses primarily on the social aspect. Patients are at the center of the subjective interest of the change. They are a key factor in the success of this process. According to Carnall, the effectiveness of change in $40 \%$ depends on solving social problems [12]. People have to learn the change, take on a new task and then solve it. Change in the social aspect is primarily its human orientation as the main focus of interest. Organizations change through people. After all, people have to assimilate change and take on new tasks. Therefore, the problem of change should be considered through the people involved in this process. A. Toffler wrote that "... the responsibility for change lies with ourselves. We must start with ourselves, learning not to shut our minds and hearts in advance of what is new, unexpected and seemingly radical [13]". In the literature devoted to the issues of change there is a great variety in presenting the problem of the patient's role in the process of change.

Some authors present the patient's needs in the process of change, others talk about the patient's attitude to change, while others deal with forms of showing resistance to changes in the healthcare system. However, it is undoubted that chances for success in the area of change should be sought in its social resources. Liz Clarke writes that "a common mistake of many organizations is underestimating the impact of change on people [14]". Organization development is also based on people, because thanks to them the organization's resources are multiplied. Each organization through its social potential is able to efficiently assimilate changes and organize its activities in such a way as to improve itself. A modern organization cannot separate its other resources from people because it would lose its identity and values. Change, and especially its course, can be a derivative of the appropriate control of the centers of forces (power) that occur in the organization, as R. L. Bittel writes [15].

The view of E.M.Rogers may be interesting here, which distinguished five types of people taking into account the speed of absorption of changes. They are: innovators, early followers, early followers, late followers, laggers [16]. Once again, it should be emphasized that in the subjective aspect of change, one should pay attention to the fact that the change processes taking place in organizations are primarily social processes. According to the American organization and management theoretician Mc Gregor, people are inherently active and responsible, they want to develop and manage their own behavior [17-20]. Mc Gregor and his theory $\mathrm{X}$ and theory $\mathrm{Y}$ (which became the starting point for the process of directing through goals) devotes a lot of space to personality and the role of man. An indispensable condition for the success of the change is the acceptance of it by the participants and readiness for behavior conditioning its assimilation. What does the object of resistance look like to changes? What sources do resistance come from? What should you do to rationally minimize resistance? How to make changes so that a person would like to submit to them and do it voluntarily instead of under duress? We are constantly looking for answers to these questions.

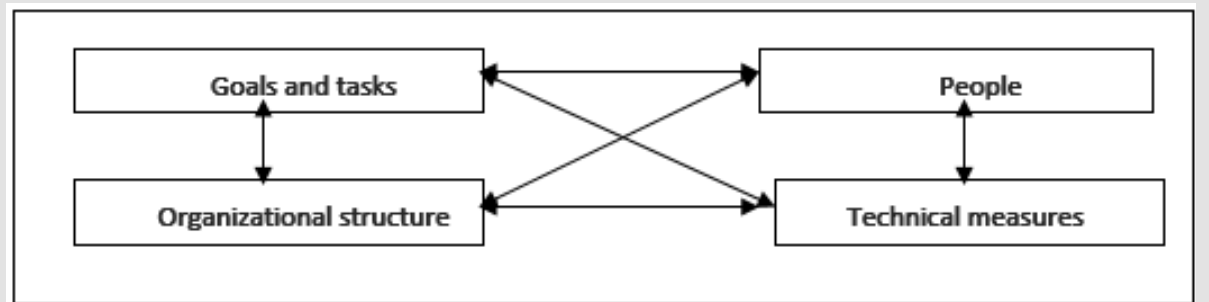

Source: H.J.Leavitt: Appelied Organisational Change in Industry. W: Handbook of Organisation. G.March (red.) Chicago 1965, s. 160.

Figure 3: Organizational system by H.J.Leavitta.

Each changed organization, regardless of the nature of the change or the motive for its creation, creates new working conditions. Almost all modern organizations (teaching, healing, production, administrative, etc.) are treated as complex sociotechnical systems. While the organizational or technical condition can be adapted to changes in the environment, for example by reorganizing the process or transferring technology, people are not easily modified. H.J. Leavitt's model is the most general and also the most universal organization model in which people occupy high rank. The essence of his model are the feedback between people, the goals of the organization, the organizational structure and technical means (Figure 3). People create their future image 
through their influence on individual elements of the organization. Man influences technical means deciding about the scope of their use. In turn, technical means force people to learn new skills in their use. The human impact on the organizational structure, on the other hand, determines the formal solutions adopted in a specific organization and informal solutions, which in an ad hoc manner and depending on the need for rapid change condition some decisionmaking powers.

The organizational structure shapes social relations, organizational roles of individual members of the organization. Against this background, we are dealing with a large human relationship with the change management process. It is worth emphasizing at this point that the starting point in these considerations is a single person or group of people who influence the success of reorganization plans Summing up the considerations of the participation of stakeholders in the process of changes in health care organizations, it can be said that their behavior in the face of changes is extremely important. These behaviors should be oriented towards efficient change management. Today (especially in the event of an epidemic crisis), as well as in the future, stakeholders should effectively participate in the process of change, prepare changes to create a good image of change. Building change requires the participation of individual stakeholders at every stage of this process. The success of changes depends above all on promoting a new reality, sharing knowledge, as well as creating mutual trust in the constantly changing face of healthcare organizations.

\section{Conclusions}

Bearing the above in mind, the author comes to the following conclusions:

1. There are many stakeholders in the healthcare system. Their significance depends on many factors: power, economic resources, the roles they play, and the impact they have on the functioning of health care.

2. All stakeholders have a very important goal to achieve - ensuring health security for the public. Regardless of whether their impact on change is large or not, it is important for everyone to make efforts to create an ever better functioning health care system, a system that everyone can afford.

3. The changing health protection system must cultivate "social capital" in which man is the highest value. Based on the words of D. Cohen and L. Prusak, it can be added to the above statement that "management in the organization of health care is not only taking risks, but caring for human capital and social capital".

4. Managers of healthcare organizations know that in order to make effective decisions about implementing changes, patients must be in the foreground. Patients constitute "capital" - an intangible asset of a healthcare organization. The position of man in the entire changing economic process of our millennium has been recognized. Assumptions of P.M.Senge in 'The Tifth Discipline. Although the Art. And Practice of The Learning Organization refer to the concept of the so-called a learning organization, but in order to be able to fulfill its most ambitious aspirations and changes, the organization must implement, among others, the so-called thought models - based on discovering the real reality about the organization and the people creating them.

\section{References}

1. Friedman AL, Miles S (2016) Stakeholders Theory and Practice, University Press Oxford, New York.

2. Stoner J, Freeman R, Gilbert D (2018) Kierowanie, Polskie Wydawnictwo Ekonomiczne, Warszawa

3. Carneal CA (2016) Managing, Change in Organizations, University Press Oxford, New York, USA.

4. Robbins S (2012) Zachowania w organizacjach, Polskie Wydawnictwo Ekonomiczne, Warszawa.

5. Crozier M, Friedbarg E (1982) Człowiek i system. Ograniczenia działania zespołowego, PWE, Warszawa.

6. Flora C (2014) Building Social Capital: The Importance of Entrepreneurial Social Infrastructure. www.ag.iastate.edu.

7. Shapiro EC (2015) Trendsurfen in der Chefetage - Unternehmenshifrung jenseits der Managementmodem, Frankfurt.

8. Willke H (2015) Systemtheorie - 3 Steuerungstheorie, Stuttgart.

9. Bonsiep W, Klich J (2019) Mid-level managers - the barrier to change or a key factor of change, Przegląd Organizacji, No. 2, pp. 20-21.

10. Mikołajczyk Z (1999) Kadra kierownicza polskich przedsiębiorstw państwowych w warunkach zmian systemu gospodarczego, Wydawnictwo Uniwersytetu Łódzkiego, Łódź.

11. Golinowska S (2004) Pożądane kierunki zmiany systemu ochrony zdrowia w Polsce. Między racjonowaniem i racjonalizacją, Centrum Analiz Społeczno-Ekonomicznych, Warszawa.

12. Golinowska S, Boni M (2006) Nowe dylematy polityki społecznej, Centrum Analiz Społeczno-Ekonomicznych, Warszawa.

13. Halal, William E (1996) The New Management. Democracy and Enterprise are Transforming Organizations, Berrett - Koehler, San Francisco.

14. Herrera J (2011) Participatory Management, Teamwork and leadership. Key Requirements for the Success of Organizations in the Twenty-first Centur. https://www.ohrd.wisc.edu/home/Portals /0/ Week1Partcipatory Management TeamworkLeadership-Herrera.pdf (12.02.2020).

15. Hodgkinson A (1999) Employee Involvement and Participation in the Organizational Change Decision: Illawarra and Australian Patterns, Working Paper 99-7, Department of Economics, University of Wollongong.

16. Rogers EM (2013) Diffusion of Innovations, New York.

17. Kohen M, Prusak L (2015) In Good Company: How Social Capital Makes Organizations Work, Harvard Business School Press", Boston.

18. Kanter R (2016) The reshaping of middle Management, [w:] Management Review.

19. Lessem R (2016) Global Management Principles, Prentice - Hall, New York.

20. Leavitt HJ (1965) Appelied Organisational Change in Industry. W: Handbook of Organization. G March (red.) Chicago. 
ISSN: 2574-1241

DOI: 10.26717/BJSTR.2020.27.004512

Joanna Jasińska. Biomed J Sci \& Tech Res

(C) This work is licensed under Creative

Submission Link: https://biomedres.us/submit-manuscript.php

$\begin{array}{ll}\text { BIOMEDICAL } & \text { Assets of Publishing with us } \\ \text { RESEARCHES } & \text { - Global archiving of articles } \\ \text { - Immediate, unrestricted online access }\end{array}$

